\title{
MOBILE LEARNING TEACHER COMPETENCIES FRAMEWORK
}

\author{
Stavros A. Nikou \\ University of Strathclyde (UNITED KINGDOM) \\ stavros.nikou@strath.ac.uk
}

\begin{abstract}
Advancements in mobile and wireless technologies have increased the adoption rate of mobile learning. Mobile learning offers numerous affordances to education: time and location independence, ubiquity and context awareness, adaptivity and personalization, social interactivity and easier administration. However, for the effective integration of mobile learning in schools, teachers should have the appropriate competencies in order to integrate mobile technologies into their professional practise.
\end{abstract}

Existing Information and Communication Technologies (ICT) frameworks provide general guidelines to pre-service and in-service teachers for the appropriate use of digital technologies across education.

Examples of such frameworks are the UNESCO ICT Competency Framework for Teachers (ICT CFT v.3), the International Society for Technology in Education (ISTE) standards and the European Framework for the Digital Competence of Educators (DigCompEdu). While the aforementioned frameworks provide a set of competencies that educators need to master in order to effectively use digital technologies in their professional practise, they are not focused on specific educational technologies.

Wireless and mobile technologies have introduced a set of characteristics that are rather unique to mobile learning: personalisation and adaptivity, ubiquity and context-awareness, interactivity and authenticity, self-directedness and collaboration.

The current study proposes the development of a framework that explicitly defines the mobile learning competencies that teachers need to have in order to effectively integrate mobile learning into their professional practise so as to enhance and innovate education and training.

The proposed framework is based on current digital competencies frameworks and incorporates the following aspects of teachers' professional practise: mobile technologies, digital citizenship, safety, classroom management, pedagogy, teaching, assessment, and professional engagement. Moreover, the framework introduces a progression model identifying three expertise levels: beginner, competent and proficient.

The proposed framework for teachers' mobile learning competencies is aiming to function in a complementary way to the current general digital competency frameworks by providing explicit links between mobile learning competencies and teachers' practise and continuous professional development.

The framework can provide a useful guidance for the development of teachers' training programs that promote mobile learning competencies and also for self-assessment to evaluate individual mobile learning competence levels. 
Keywords: digital competencies, technology, teacher professional development, mobile learning, framework.

\section{INTRODUCTION}

Digital technologies introduce main benefits to education; they support and enhance learning, they help developing twenty-first century skills and promote digital citizenship and lifelong learning [1]. However, for the successful implementation of any technology enhanced learning, it is essential that teachers have the competencies to integrate digital technologies in their professional practice.

While most European teachers consider that digital technologies can have a positive impact on student learning, their own confidence to use digital technologies is rather low [2]. International organisations report that there is an urgent need to improve teachers' digital competencies [3]. The development of teachers' digital competencies has become a priority in many educational policies [4].Teachers should be able to harness the affordances of ICT not only to deliver high quality teaching but also to support students in the development of their own digital competencies. Towards this direction, a considerable number of frameworks have been proposed to guide the development of digital skills [5].

Among the different educational technologies available today, mobile learning is a growing educational practise $[6,7]$. Mobile learning is 'learning across multiple contexts, through social and context interactions, using personal electronic devices' [8]. Due to their increased power, connectivity, functionality and affordability, mobile devices have become an emerging instructional tool. Mobile technologies provide new and enhanced learning opportunities, such as personalization and adaptivity, context-awareness and ubiquity, interactivity, communication and collaboration among learners, and seamless bridging between contexts in both formal and informal learning $[9,10,11]$. Previous review studies indicate that mobile learning has a great potential in indoor and outdoor learning $[12,13,14,15]$. However, the lack of teachers' digital competencies is an important barrier towards the adoption of mobile learning [16, 17, 18]. Therefore, teachers need to develop their mobile learning skills in order to be able to integrate mobile technology in their teaching [19]. The current study proposes a conceptual framework that can guide the development of teachers' digital competence in the context of mobile learning.

\section{BACKGROUND}

\section{Digital Competency Frameworks for Teachers}

Digital competence is one of the key competencies that individuals need to have for their personal and social development, active citizenship and employment [20]. Digital competence is defined as "the confident and critical use of Information Society Technology (IST) for work, leisure and communication. It is underpinned by basic skills in ICT: the use of computers to retrieve, assess, store, produce, present and exchange information, and to communicate and participate in collaborative networks via the Internet" [20]. There are different frameworks for the development of digital competencies of citizens. DigComp 2.1 is one of the most well-known digital competence frameworks [21]. The framework emphasizes on information and data literacy, communication and collaboration, safety, content creation and problem solving. Among the main current digital competencies frameworks [5], the following three focus on teachers' 
digital competencies: the UNESCO ICT Competency Framework for Teachers (ICT CFT) [22], the European Framework for the Digital Competence of Educators [23] and the International Society for Technology in Education (ISTE) Standards for Educators [24]. These frameworks identify key competencies in terms of the knowledge, skills and attitudes that teachers need to have in order to effectively integrate Information and Communication Technologies in their professional practice.

The UNESCO ICT Competency Framework for Teachers (ICT CFT) Version 3 [22] addresses six aspects of teacher's professional practice: understanding ICT in education policy, curriculum and assessment, pedagogy, application of digital skills, organization and administration and teacher professional learning. Also, the ICT CFT is organized over three successive stages of a teacher's development: knowledge acquisition (basic technology and basic ICT competencies), knowledge deepening (facilitate student-centred and collaborative learning environments) and knowledge creation (facilitate learning environments that encourage new knowledge creation from students). The ICT CFT informs teacher-training policies and programmes to strengthen the use of ICT in Education.

The Digital Competence Framework for Citizens [21] captures five competence areas for citizens: information and data literacy, communication and collaboration, digital content creation, problem solving and safety with eight proficiency levels. The European Framework for the Digital Competence of Educators [23] promotes the use of digital technologies for enhancing and innovating education. The framework proposes 22 elementary educator-specific competences organised in 6 areas: professional engagement (using digital technologies for communication, collaboration and professional development), digital resources (sourcing, creating and sharing digital resources), teaching and learning (managing and orchestrating the use of digital technologies in teaching and learning), assessment (using digital technologies and strategies to enhance assessment), empowering learners (using digital technologies to enhance inclusion), personalisation and learners' active engagement) and facilitating learners' digital competence (enabling learners to creatively and responsibly use digital technologies for information, communication, content creation, wellbeing and problem-solving). The framework indents to support national, regional and local efforts in supporting teachers' digital competence in Europe.

The International Society of Technology in Education (ISTE) Standards [24] characterizes educators as being learners, leaders, citizens, collaborators, designers, facilitators and analysts. According to the framework, technology plays a crucial role in facilitating teachers to improve their practice, seek leadership opportunities, be responsible digital citizens, collaborate with colleagues and students, design learner-centered educational environments, facilitate learning with technology and use data to inform their professional practice. Educators should be able to use digital technologies to develop learning environments that engage, support, and inspire students, communicate and collaborate with others and promote digital citizenship.

\section{Mobile Learning}

All the aforementioned frameworks refer to general digital competencies that teachers need to have in order to effectively integrate digital technologies in their professional practise. However, different educational technologies have their own individual characteristics. Mobile devices, including smartphones and tablets have become very popular learning devices [25]. They can offer more creative, personalised and flexible - anytime and anywhere - approaches to learning, 
improving students' motivation, engagement and even performance [12, 14]. Among the key characteristics that make mobile learning distinctive are: interactivity and adaptivity [26], authenticity, collaboration and personalisation [27], ubiquity, context awareness and seamlessness [28]. However, lack of teacher confidence, knowledge and skills is a main barrier towards the adoption of mobile technologies in the classroom [16]. Moreover, research reports a lack of studies on teacher preparation program standards integrating mobile technology [29]. The current study proposes a conceptual framework for teachers' mobile learning competencies.

\section{THE MOBILE LEARNING COMPETENCY FRAMEWORK}

The proposed framework, based on current digital competencies frameworks, defines a set of competencies that teachers need to have in order to effectively integrate mobile learning into their professional practise aiming to enhance and innovate education and training. The framework incorporates the following eight aspects of teachers' professional practise: mobile technologies, digital citizenship, safety, classroom management, pedagogy, teaching, assessment and professional engagement (figure 1).

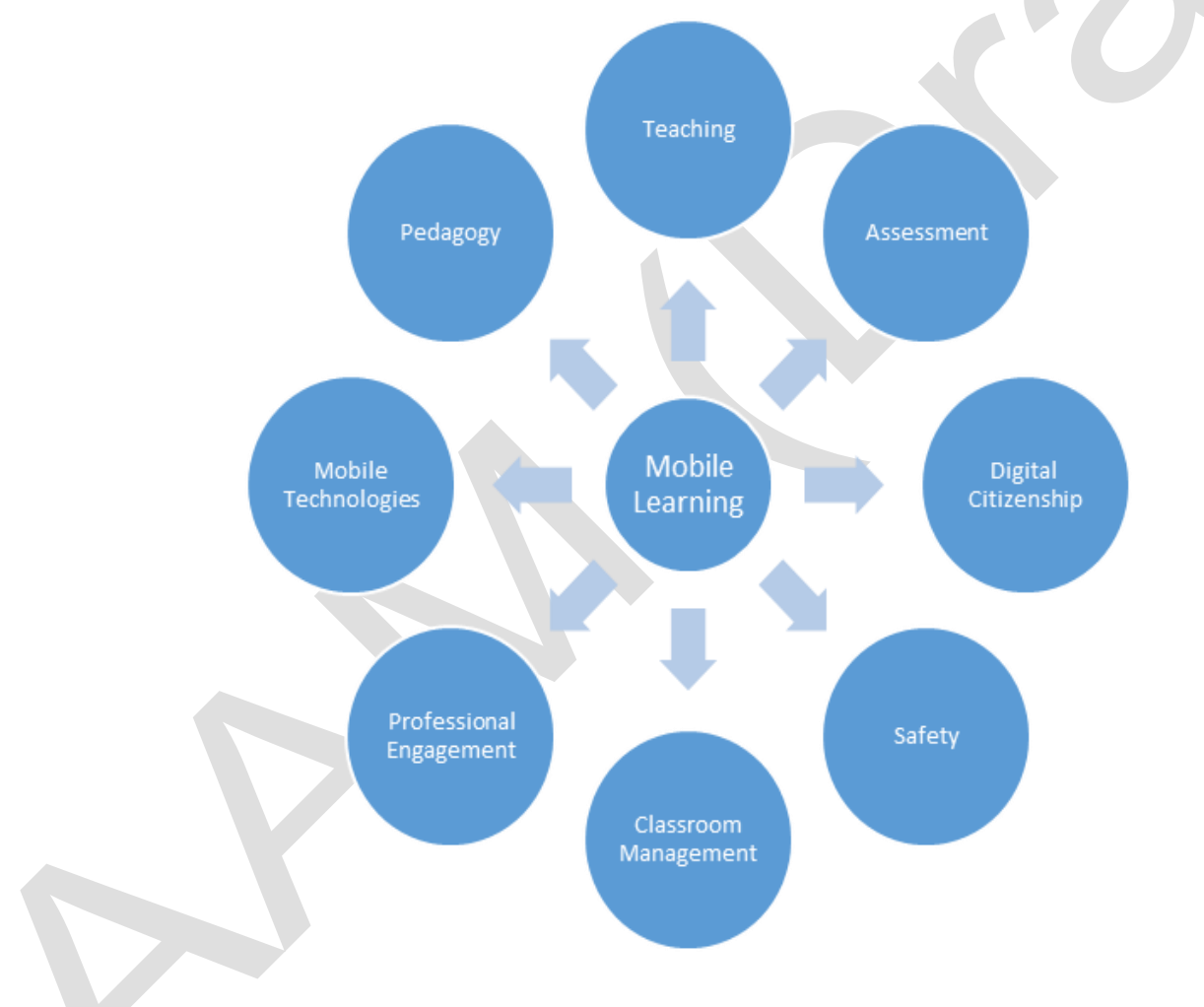

Figure 1. Mobile learning competency framework for teachers.

The first area (mobile technologies) is about the ability to effectively use the mobile devices: navigate through the different functionalities (e.g. camera, multimedia), connect online, perform routine monitoring, install general purpose or educational apps, customise and even create new educational apps. The second area (digital citizenship) refers to the active and ethical online behaviour that incorporates both user rights and responsibilities. It also incorporates physical, psychological and social wellbeing (e.g. ergonomic issues, control of possible negative feelings associated with smartphone overuse). The third area (safety) is about identifying risks and threads and protecting mobile devices and data from digital attacks (e.g. passwords, anti-virus, privacy and security settings). The fourth area (classroom management) refers the capacity to 
effectively control classroom behaviour in order to eliminate the negative effects of mobile technologies (e.g. student distraction, classroom disruption).

The fifth area (pedagogy) refers to the appropriate use of mobile technologies in order to support different pedagogies (e.g. e-portfolios to collect evidence for inquiry-based approach, flipped classroom, social media for collaboration, game-based learning or self-directed learning). The sixth area (teaching) is the ability to use appropriate mobile tools and apps to enhance teaching by making it more interacting and engaging (e.g. teaching strategies that offer situated, contextualised and personalised support, use of augmented reality apps or simulations ).

The seventh area (assessment) refers to the capacity of using mobile technologies to deliver different kinds of assessments (from simple polling apps for quizzes to more advanced means of assessment such as context-aware adaptive quizzes with meaningful personalised feedback).The eighth area (professional engagement) is about using mobile devices to communicate with parents, colleagues or other networks, to engage in administration and other organisational tasks (e.g. record keeping, timetabling) and also to participate in communities of practise to further develop mobile learning competencies.

Moreover, the proposed framework introduces a progression model that identifies three expertise levels: beginner, competent and proficient. Therefore, the eight aforementioned areas develop through the three progression levels of beginner, competent and proficient. The beginner level refers to an entry and initial adoption level of mobile learning. The competent level describes an appropriation and integration level. The proficient level describes an advanced level of mobile learning leadership.

\section{CONCLUSIONS AND FUTURE RESEARCH}

Mobile learning competencies are vital for today's teachers in order to be able to harness the affordances of mobile technologies and further promote $21^{\text {st }}$ century skills such as collaboration, critical thinking, problem solving and creativity. Teacher training should highlight mobile learning as an authentic, interactive, personalised, collaborative, ubiquitous, flexible, and engaging way of learning.

The current study proposes a conceptual framework for teachers' mobile learning competencies. It is based on current frameworks on general digital competencies and focuses on those competencies that teachers need to have in order to effectively integrate mobile learning into their professional practise.It is a two dimensional framework that incorporates eight aspects of teachers' professional practise along with three expertise levels. The mobile learning practices are mobile technologies, digital citizenship, safety, classroom management, pedagogy, teaching, assessment and professional engagement. The three levels of expertise are beginner, competent and proficient. The framework encourages teachers, as digital citizens, to actively engage in mobile learning supporting different instructional methods and their own professional development.

The framework can provide a useful guidance for the development of pre-service teachers' training programs and in-service teachers' continuous professional development programs aiming to promote mobile learning competencies. Also, the framework can be useful for selfevaluation of individual mobile learning knowledge and skills and motivate teachers to further improve.

In a future study we will propose a self-assessment instrument that can be used by teachers to self-evaluate their own mobile learning competencies. 
Table 1 summarizes the eight areas of the framework along with the three progression levels.

Table 1. Areas and progression levels of mobile learning teachers' competencies

\begin{tabular}{|c|c|c|c|}
\hline & Beginner & Competent & Proficient \\
\hline $\begin{array}{l}\text { Mobile } \\
\text { technologies }\end{array}$ & $\begin{array}{l}\text { Basic use of mobile } \\
\text { based hardware and } \\
\text { software. }\end{array}$ & $\begin{array}{l}\text { Competent use of } \\
\text { different mobile } \\
\text { technologies. } \\
\text { Ability to use mobile } \\
\text { learning content. }\end{array}$ & $\begin{array}{l}\text { Expert use of } \\
\text { different mobile } \\
\text { technologies. } \\
\text { Ability to create and } \\
\text { share mobile } \\
\text { learning content. }\end{array}$ \\
\hline $\begin{array}{l}\text { Digital } \\
\text { Citizenship }\end{array}$ & $\begin{array}{l}\text { Acknowledge ethical } \\
\text { and responsible } \\
\text { online behaviour, } \\
\text { and health and well- } \\
\text { being associated } \\
\text { with the use of } \\
\text { mobile devices. }\end{array}$ & $\begin{array}{l}\text { Raise awareness } \\
\text { about ethical and } \\
\text { responsible online } \\
\text { behaviour in class, } \\
\text { and health and well- } \\
\text { being associated } \\
\text { with the use of } \\
\text { mobile devices. }\end{array}$ & $\begin{array}{l}\text { Develop teaching } \\
\text { practices and } \\
\text { resources that } \\
\text { promote ethical and } \\
\text { responsible online } \\
\text { behaviour, and } \\
\text { health and well- } \\
\text { being associated } \\
\text { with the use of } \\
\text { mobile devices. }\end{array}$ \\
\hline Safety & $\begin{array}{l}\text { Acknowledge } \\
\text { general cyber } \\
\text { security issues } \\
\text { related to the use of } \\
\text { mobile devices and } \\
\text { apply basic device } \\
\text { and data protection. }\end{array}$ & $\begin{array}{l}\text { Identify important } \\
\text { threads and risks } \\
\text { related to the use of } \\
\text { mobile devices and } \\
\text { apply various } \\
\text { methods for device } \\
\text { and data protection. }\end{array}$ & $\begin{array}{l}\text { Fully understand the } \\
\text { variety of security } \\
\text { threads for mobile } \\
\text { devices and support } \\
\text { students to mobile } \\
\text { cybersecurity. }\end{array}$ \\
\hline $\begin{array}{l}\text { Classroom } \\
\text { management }\end{array}$ & $\begin{array}{l}\text { Understand how } \\
\text { students interact } \\
\text { with mobile devices } \\
\text { in class. }\end{array}$ & $\begin{array}{l}\text { Discuss and set up } \\
\text { mobile device usage } \\
\text { expectations from } \\
\text { students }\end{array}$ & $\begin{array}{l}\text { Establish a } \\
\text { classroom behaviour } \\
\text { that takes advantage } \\
\text { of the educational } \\
\text { potential of mobile } \\
\text { devices and } \\
\text { minimises possible } \\
\text { distractions. }\end{array}$ \\
\hline Pedagogies & $\begin{array}{l}\text { Be aware of different } \\
\text { mobile learning } \\
\text { resources able to } \\
\text { support pedagogies. }\end{array}$ & $\begin{array}{l}\text { Support certain } \\
\text { pedagogies by } \\
\text { integrating existing } \\
\text { mobile learning } \\
\text { resources. }\end{array}$ & $\begin{array}{l}\text { Empower student } \\
\text { learning by } \\
\text { incorporating } \\
\text { innovative mobile } \\
\text { based pedagogical } \\
\text { approaches. }\end{array}$ \\
\hline
\end{tabular}




\begin{tabular}{l|l|l|l}
\hline Teaching & $\begin{array}{l}\text { Use mobile } \\
\text { technologies to } \\
\text { limitedly support } \\
\text { teaching and } \\
\text { learning. }\end{array}$ & $\begin{array}{l}\text { Use mobile } \\
\text { technologies to } \\
\text { functionally improve } \\
\text { teaching and } \\
\text { learning }\end{array}$ & $\begin{array}{l}\text { Extend the use of } \\
\text { mobile technologies } \\
\text { to offer innovative } \\
\text { teaching that could } \\
\text { not be offered } \\
\text { without mobile } \\
\text { technology. }\end{array}$ \\
\hline Assessment & $\begin{array}{l}\text { Design and } \\
\text { implement simple } \\
\text { mobile-based } \\
\text { assessments using } \\
\text { basic mobile apps } \\
\text { and tools. }\end{array}$ & $\begin{array}{l}\text { Design and } \\
\text { implement more } \\
\text { complex mobile- } \\
\text { based assessments } \\
\text { using different } \\
\text { mobile apps and } \\
\text { tools. }\end{array}$ & $\begin{array}{l}\text { Design and } \\
\text { implement } \\
\text { sophisticated } \\
\text { mobile-based } \\
\text { assessments using a } \\
\text { wide range of } \\
\text { mobile apps and } \\
\text { tools. }\end{array}$ \\
\hline $\begin{array}{l}\text { Professional } \\
\text { engagement }\end{array}$ & $\begin{array}{l}\text { Use mobile } \\
\text { technologies to } \\
\text { communicate with } \\
\text { the educational } \\
\text { community. }\end{array}$ & $\begin{array}{l}\text { Use mobile } \\
\text { technologies to } \\
\text { communicate and } \\
\text { collaborate with the } \\
\text { educational } \\
\text { community. }\end{array}$ & $\begin{array}{l}\text { Use mobile } \\
\text { technologies for } \\
\text { lifelong professional } \\
\text { development. }\end{array}$ \\
\hline \hline
\end{tabular}

\section{REFERENCES}

[1] W. Ng, "New Digital Technology in Education, Conceptualizing Professional Learning for Educators", Switzerland: Springer International Publishing, 2015.

[2] G. Abbiati, D. Azzolini, A. Balanskat, D. Piazzalunga, E. Rettore, \& A. Schizzerotto, "MENTEP Executive Report, Summary of results of the field trials: The impact of the technology-enhanced self-assessment tool (TET-SAT)”, Brussels: European Schoolnet, 2018.

[3] Organisation for Economic Co-operation and Development (OECD), "Are students ready for a technology-rich world? What PISA studies tell us”, Paris: OECD, 2010.

[4] Eurydice, "Key Data on Learning and Innovation through ICT at School in Europe 2011", European Commission, 2011. Accessed April 19, 2020. Retrieved from https://op.europa.eu/en/publication-detail/-/publication/8f864668-0211-4a40-bc1465bf1a97b6a8

[5] A. Ferrari, "Digital competence in practice: An analysis of frameworks", Joint Research Centre, 2012. Accessed 16 April, 2020. Retrieved from http://ftp.jrc.es/EURdoc/JRC68116.pdf

[6] L. Johnson, S. Adams Becker, V. Estrada, \& A. Freeman, "NMC Horizon report: 2014 higher education edition”, Austin, TX: The New Media Consortium, 2014a.

[7] L. Johnson, S. Adams Becker, V. Estrada, \& A. Freeman, "NMC horizon report: 2014 K-12 edition”, Austin, TX: The New Media Consortium, 2014b.

[8] H. Crompton, "A historical overview of mobile learning: Toward learner-centered education". In Z. L. Berge \& L. Y. Muilenburg (Eds.), Handbook of mobile learning (pp. 314). Florence, KY: Routledge, 2013. 
[9] Y.-T. Sung, K.-E., Chang, \& T.-C. Liu, "The effects of integrating mobile devices with teaching and learning on students' learning performance: A meta-analysis and research synthesis", Computers \& Education, vol. 94, pp. 252-275, 2016.

[10] M. West, \& S. E. Vosloo, “UNESCO policy guidelines for mobile learning”, Paris: UNESCO, 2013.

[11] W.-H. Wu, Y.-C. J., Wu, C.-Y. Chen, H.-Y. Kao, C.-H. Lin, \& S.-H. Huang, "Review of trends from mobile learning studies: A meta-analysis". Computers \& Education, vol. 59, no. 2, pp. 817-827, 2012.

[12] K.N. Chee, N. Yahaya, N.H. Ibrahim, \& M. Noor Hassan, "Review of mobile learning trends 2010-2015: A meta-analysis", Educational Technology \& Society, vol. 20, no. 2, pp.113-126, 2017.

[13] G.-J Hwang, \& P.-H. Wu, "Applications, impacts and trends of mobile technologyenhanced learning: A review of 2008-2012 publications in selected SSCI journals", International Journal Mobile Learning and Organization, vol. 8, no.2, 2014.

[14] S.A. Nikou, \& A.A. Economides, "Mobile-Based micro-Learning and Assessment: Impact on learning performance and motivation of high-school students". Journal of Computer Assisted Learning, vol. 34, no. 3, pp. 269-278, 2018.

[15] S.A. Nikou, \& A.A. Economides, "Mobile-based assessment: A literature review of publications in major referred journals from 2009 to 2018". Computers \& Education, vol. 125, pp. 101-119, 2018.

[16] S.A. Nikou, \& A.A. Economides, "Factors that influence Behavioral Intention to Use Mobile-Based Assessment: a STEM teachers' perspective”, British Journal of Educational Technology, vol. 50, no. 20, pp. 587-600, 2018.

[17] K. Mac Callum, L. Jeffrey, \& Kinshuk, "Factors impacting teachers' adoption of mobile learning". Journal of Information Technology Education Research, vol. 13, 2014. Accessed April 19, 2020. Retrieved from http://www.jite.org/documents/Vol13/JITEv13ResearchP141-162MacCallum0455.pdf

[18] J.C. Sanchez-Prieto, S. Olmos-Miguelanez, \& F.J. Garcia-Penalvo, "MLearning and preservice teachers: an assessment of the behavioral intention using an expanded TAM model". Computers in Human Behavior, vol. 72, pp. 644-654, 2017.

[19] C. Ditzler, E. Hong, \& N. Strudler, "How tablets are utilized in the classroom". Journal of Research of Technology in Education, vol. 48, no. 3, pp.181-193, 2016.

[20] European Parliament and the Council, "Recommendation of the European Parliament and of the Council of 18 December 2006 on key competences for lifelong learning". Official Journal of the European Union, L394/310. Accessed April 19, 2020. Retrieved from https://eur-lex.europa.eu/legal-content/EN/TXT/?uri=celex:32006H0962

[21] S. Carretero, R. Vuorikari, R. \& Y. Punie, 2017), "DigComp 2.1: The Digital Competence Framework for Citizens with eight proficiency levels and examples of use", 2017, EUR 28558 EN, doi: $10.2760 / 3884$

[22] UNESCO, “UNESCO ICT Competency Framework for Teachers, version 3”, United Nations Educational, Scientific and Cultural Organization, 2018. Accessed 16 April, 2020. Retrieved from https://unesdoc.unesco.org/ark:/48223/pf0000265721

[23] European Commission, JRC Science for Policy Report, "European Framework for the Digital Competence of Educators (DigCompEdu)”, 2017. Accessed 16 April, 2020. 
Retrieved from https://ec.europa.eu/jrc/en/publication/eur-scientific-and-technical-researchreports/european-framework-digital-competence-educators-digcompedu

[24] International Society for Technology in Education, "ISTE Standards for Educators", Accessed 16 April, 2020. Retrieved from https://www.iste.org/standards/for-educators

[25] Q.-K. Fu, G.-J. Hwang, "Trends in mobile technology-supported collaborative learning: A systematic review of journal publications from 2007 to 2016", Computers \& Education, vol. 119, pp.129-143, 2018.

[26] R. Huang, J. Yang, \& Y. Hu, (2012), "From digital to smart: The evolution and trends of learning environment", Open Education Research, vol.1, pp. 75-84, 2012.

[27] M. Kearney, S. Schuck, K. Burden, \& P. Aubusson, "Viewing mobile learning from a pedagogical perspective”, Research in Learning Technology, vol.20, no.1, 2012.

[28] G. Hwang, (2014). "Definition, framework and research issues of smart learning environments: A context-aware ubiquitous learning perspective", Smart Learning Environments, vol.1, no.1, pp.1-14, 2014.

[29] S. Hicks \& D. Bose, "Designing Teacher Preparation Courses: Integrating Mobile Technology, Program Standards, and Course Outcomes", TechTrends, vol. 63, pp.734-740, 2019. 